\title{
International Market Orientation and Management Capabilities as Determinants of the New Ventures' International Behaviour
}

\author{
Diego Monferrer, Andreu Blesa, and María Ripollés \\ Department of Business Administration and Marketing, Universitat Jaume I, Vicente Sos Baynat, s/n, 12071 Castellón, Spain \\ Correspondence should be addressed to Diego Monferrer, dmonferr@uji.es
}

Received 23 March 2012; Revised 14 June 2012; Accepted 15 June 2012

Academic Editor: Udo Broll

Copyright (C 2012 Diego Monferrer et al. This is an open access article distributed under the Creative Commons Attribution License, which permits unrestricted use, distribution, and reproduction in any medium, provided the original work is properly cited.

\begin{abstract}
The main research objectives of this paper are the analysis of the influence of international market orientation and the management capabilities derived from that orientation on international new ventures' (INVs) behavior. Foreign market geographical diversification and the commitment involved in entry modes are considered to reflect this international behavior. Thus existing International Entrepreneurship literature is developed by analyzing the behavior of INVs explaining and testing how international market orientation and management capabilities affect geographical diversification and the commitment involved in entry modes. The empirical study confirms this influence.
\end{abstract}

\section{Introduction}

It has traditionally been argued that firms need time to obtain the necessary resources to deal with the problems and challenges of internationalization [1,2]. But in 1993, a study of the consultants McKinsey for the Australian Manufacturing Council identified a new type of firm that moves into foreign markets soon after creation $[3,4]$. These firms have been widely referred to as International New Ventures (INVs). Since Oviatt and McDougall's [5] seminal article, which defined INVs as "new firms which enter foreign markets rapidly and obtain significant competitive advantages from the use of international resources and the sale of products/services on different markets," the study of the factors that could encourage early international behavior in new firms has attracted the attention of researchers in the fields of entrepreneurship, internationalization, and marketing [6-9]. All these studies have contributed to our understanding of the reasons that drive early internationalization in these firms. However, rapid international expansion alone is not a sufficient strategy for INVs.

In a firm's internationalization process, one key strategic decision is international market selection [10-13]. Entering new markets, in particular foreign markets, involves a major commitment of recourses (strategic, technical, managerial, and financial). Due to the limitation of resources, a firm has to make a strategic decision on which markets to enter and allocate resources accordingly [14]. This decision is especially important in the case of companies that decide to be international from the inception, as INVs. Nevertheless few efforts have been done in explaining why and how INVs decide to enter in one or more countries.

With little consideration of individual firm's resources and capabilities past research, particularly the gradualist model [15], argues that firms seeking to enter an international market are more likely to use cultural distance [16]: beginning with a culturally close market and expanding to a culturally distant market when becoming more experienced. This model perceives the internationalization of the firms as being a sequential process that leads from a domestic market to international markets in accordance with a "learning process," whereby knowledge of the new markets is acquired and resources are increasingly committed to those markets $[1,2,17,18]$.

However, the international behaviour demonstrated by INVs cannot be understood under the deterministic assumptions made by the gradualist models. The emergence of this new type of firm has therefore opened up gaps in 
the literature that demand new theoretical approaches with which to analyze them [19-22], providing an understanding of this new business reality and helping the managers of such firms to overcome the liabilities of newness and foreignness they face.

Previous research has shown that the possession of certain competences can facilitate the development of a company's internationalization strategy, especially in the earlier stages of the process $[23,24]$. In fact, according to Gabrielsson et al. [25] and Blesa et al. [26], what makes it possible to distinguish between different types of international behaviors in new firms are the commitment of resources in the foreign markets where the new firm operates and the geographical diversification of their foreign markets. However, a comprehensive explanation of the strategic antecedents of INVs' international behavior is still not adequately addressed in extant models of internationalization [27].

In this paper we address this shortcoming in order to advance in the knowledge of behavior in new ventures that become international early. In order to do that, the study draws on a multidisciplinary marketing and management view to arguing that market orientation and the management capabilities it implies are determinants of the international behavior of INVs, represented by their entry mode choice and geographical diversification.

Thus, firms can use their international market orientation to overcome cultural distance problems, especially information asymmetry, opportunistic behavior, and uncertainty. Market-oriented behaviors facilitate acquisition and dissemination of knowledge and responsiveness to this intelligence about foreign markets what is especially important when the firm has no international experience $[9,26,28-30]$. In this sense, international market orientation can be represented as an antecedent of the internationalization process of INVs because it fosters and facilitates the learning process in foreign markets and develops stronger management capabilities that allow the acquisition of foreign market knowledge, as well as designing a proper market response [30], which will determine their choice of entry modes in foreign markets and on the geographical diversification of their markets. In sum, this paper adopts the perspective that the different forms of internationalization may be decided in response to different strategic goals rather than as stages in a gradual process [31].

The contribution of this study to the existing literature is multiple. By centering its attention on strategic variables as determinants of internationalization decisions, our research provides a complementary explanation to the exiting ones focused on factors noncontrolled by the companies as lack of resources, industry, or size. Additionally, providing antecedents of INVs behaviours this paper makes a contribution to international entrepreneurship literature with an alternative perspective to the sequential process. Moreover, following Jones and Young [32], who highlight the need to consider entry mode literature when studying the entry modes used by new ventures, our theoretical model is based on arguments coming from international entrepreneurship literature, marketing literature, and entry mode literature. With this approach, our study also answers the call for multidisciplinary research in international entrepreneurship $[33,34]$.

The rest of the work begins by presenting the relationships shaping the proposed model and developing the working hypotheses. Then it follows a description of the method used to test the proposed hypotheses and a presentation of the results for a sample of early international firms. Finally, we offer a discussion of the results, the limitations, implications of the study, and possible future lines of research.

\section{Hypotheses Development}

\subsection{International Market Orientation and Management} Capabilities in INVs. Taking the two main market orientation approaches and their definitions [35, 36], marketoriented organization can be defined as one that develops coordinated behaviors among the various functions of the organization dedicated to seeking and gathering information on consumers, competitors, and the general environment in its international markets. This information is disseminated across the organization and a response is designed and implemented in accordance with the information obtained. Distinctive capabilities in the organization are identified and constructed, with the aim of satisfying consumers by providing superior value. In this paper the market orientation construct is adapted to international markets. What differentiates international market orientation from broader marketoriented activities is that international market orientation is focused towards international markets' current and future needs, competition within the firm's international markets, and other exogenous factors influencing the firm's international performance [37]. International market orientation develops behaviors that tend to improve the INV's internal and external information flow in such a way that the INV can explore changes in its international environment more rapidly and adapt its actions to the specific needs of each market. Thus, international market orientation can play a determining role in explaining not only how an INV acquires foreign business, institutional and international information, but also how these firms manage this information to develop new knowledge [26, 30, 38].

Meanwhile management capabilities are related to INVs' expertise in managing information and knowledge of international markets [39]. Concretely, management capabilities [39] include (1) market perception capabilities, such as those associated to market research; (2) market affinity capabilities, such as those related to managing customer relations; (3) cross capabilities, including the ability to share and disseminate information through the organization, coordination mechanisms to integrate market knowledge in internal processes, and abilities related to developing new products or services. This definition of capabilities has been widely used in the specialized literature due to its emphasis on learning and the company's absorption ability [40-42]. In addition, in the last decade the literature has attempted to incorporate the relational approach to the conceptualization of capabilities and many studies incorporate relational 
capabilities as a type of management capability [43, 44]. These relational capabilities emphasize the abilities generated in-company to create, maintain and exploit strategic alliances through industries.

Based on these conceptualizations of international market orientation and management capabilities we have to take into account that INVs have to overcome the challenges of size and youth as well as the challenges of operating in foreign markets [45]. Size and youthfulness usually entail the lack of resources characteristic of new ventures. The challenges associated to international activity ("liabilities of foreignness") refer to the advantages local firms usually have in relation to foreign firms when it comes to establishing commercial relations in those markets as INVs have to learn the unwritten rules governing business in the different markets where they operate $[46,47]$. In this sense various studies point to organizational knowledge as a key factor for the ongoing development of the necessary skills to maintain the firm's competitiveness in a changing environment [4850], thereby enabling the firm to overcome the challenges of international activity. In these studies, organizational knowledge is seen as a system for managing the construction, definition, access, organization, dissemination and use of knowledge assets in all their forms to help the firm create, share and use knowledge effectively [51, 52], thus consolidating a permanent, ongoing learning process in the firm.

From this perspective, organizational learning becomes a key factor in the efficient development of new capabilities [53]. International expansion provides INVs with learning opportunities through exposure to new global markets, the internationalization of new concepts, ideas from new cultures, access to new resources, exposure to new competitors and terms of competition [54]. These learning opportunities bring as a result the development of a international market orientation which helps to identify and assess them and, on the basis of this analysis, to generate the capabilities applicable to the new international environments [54]. This circumstance leads INVs to develop a complete strategic vision of their business, thereby contributing to the generation of key capabilities $[39,55]$ in making the most of business opportunities identified in the markets. Thus, the market information processes which are at the core of international market orientation, improve and constantly update the values and skills for the firm's organizational learning [56] and help to define an organizational capacity which enables a company to develop more appropriate distinctive activities [57]. In fact, most works have pointed that management capacities are present to a greater degree in market-oriented organizations [39, 55, 58, 59], which therefore makes market orientation the main source for distinguishing capacities [55].

$H_{1}$ : Higher levels of international market orientation foster the development of management capabilities in INVs.

\subsection{Management Capabilities and Higher Commitment Entry} Modes in INVs. Authors have offered different typologies of market entry modes in relation to outward activities. The approach pursued here follows that of Anderson and
Gatignon [60], McAuley [61], and Jones and Young [32] in which modes represent a spectrum of involvement ranging from indirect exporting through wholly owned firms. This categorization assumes that the different methods represent a continuum of control, commitment, and risk, which implies differences in their effectiveness in actually transferring resources and capabilities $[32,60]$. Licenses are at the lowest end of the entry mode resource commitment continuum as they involve low resource commitment by the licensing firm, which is limited to training the relevant personnel in the licensing firm. At the other extreme is direct foreign investment, where the firm assumes all the costs associated with entry, opening, or business start-up in the new market or total or partial acquisitions. Other alternatives representing intermediate values on the continuum are also found, such as joint ventures.

INVs must transfer not only their products and/or services to their foreign markets but also the way in which they relate to their markets, that is, their capabilities. In fact, management capabilities seem to be behind the international success of these companies as argued above. In this transfer process, the choice of entry mode plays a determining role.

It has been pointed out by gradualist models that high resource commitment entry modes are not a realistic way into international markets in the early stages [61]. Accordingly INVs should opt for lower resource commitment foreign entry modes in order to reduce the risk associated to internationalization, especially due to lack of resources and institutional knowledge [62]. But this is not the case for INVs. INVs' behavior seems to reflect a different way of thinking [28].

Grounding on transactional cost tradition, the transfer of know-how with a high tacit component can expose the INV to a higher dissemination risk (refers to the risk that firm's specific advantages might be expropriated through a license or by a partner in a joint venture) because this type of know-how cannot easily be protected by patents [60]. As a consequence, transmission of such know-how implies significant transaction costs, owing to a high dissemination risk; as a result, INVs are more likely to choose entry modes that involve higher commitment in foreign markets when transferring tacit know-how [63-65]. In this regard, the use of entry modes involving lower resource commitment in foreign markets has an undesirable counterpart for INVs who have developed valuable management capabilities. When INVs have management capabilities, higher resource commitment entry modes tend to outperform lower resource commitment entry modes. Management capabilities are based on tacit knowledge [54], are firm-specific [66], valuable to customers, and are not easily codified or articulated $[54,67,68]$, so they are not easily transferable. Transmission of such capabilities may lead to serious valueerosion and loss of competitive advantage for INVs. As a result, INVs are more likely to choose entry modes that give them greater control of capabilities when transferring tacit know-how capabilities [64, 65], especially because these capabilities are essential to understanding long-term competitive advantage in INVs. In this case, the choice will be associated with higher profits, because the use of cooperation-based modes could 
erode the INVs' competitive advantage. Following the above arguments, in this paper we propose the following.

$\mathrm{H}_{2}$ : Higher INVs' management capabilities foster the choice of higher commitment entry modes.

\subsection{Management Capabilities and Geographical Diversifi-} cation in INVs. Researchers have long been interested in international diversification, defined as "firms' expansion across the borders of global regions and countries into different geographic locations, or markets" [64, 69]. Although some scholars argue that INVs follow an accelerated gradual process [70], most of these authors consider that INVs characteristically operate simultaneously in various foreign markets $[71,72]$. Thus, in the process of internationalization, INVs are less dependent on established businesses in specific regions, as they tend to focus on specific market niches rather than specific geographical regions [20, 73]. However, INVs do compete locally with established competitors in their foreign markets. The geographical diversification of INVs means that they must be able to develop processes which provide them with information on the different competitive and institutional environments associated to each new foreign market. They must also be able to develop processes which guarantee coordination between different local markets and facilitate the transfer and integration of the information on each local market in their knowledge base. This transnational behaviour obliges the INV entrepreneur to develop business processes that allow resources developed at a local level to be used on a global scale [74].

The development of management capabilities facilitates not only the satisfaction of local demands but also can help INVs become familiar with the various marketing decisions that these firms should adopt in order to compete successfully in the new market, which in turn helps to improve the INV's international learning behavior. Moreover, bearing in mind that management capabilities are the result of developing the process of integration and coordination of market information, the development of capabilities will contribute to INVs better management of more varied and valuable international knowledge. Thus, it will strengthen the INVs' ability to operate internationally in various market contexts. As a consequence, management capabilities not only reduce the possibilities of failure on entering new markets, but also lower the perception of risk that entrepreneurs have about entering new markets and, therefore, their willingness to do so [75].

The development of management capabilities can thus lead INV entrepreneurs to adopt a more positive attitude towards new foreign markets [76], allowing INVs to gain greater international exposure, thereby diversifying their presence in foreign markets [77]. We therefore propose the following.

$\mathrm{H}_{3}$ : INVs' greater management capabilities foster greater international geographical diversification.

These hypotheses shape a model which situates management capabilities as determinant of INV's international behavior, characterized by the use of higher commitment entry modes and higher geographical diversification (see Figure 1).

\section{Methodology}

3.1. Sample. To test these hypotheses, data were collected from a sample of Spanish INVs operating in several industries. Firms were selected from the Dun \& Bradstreet database, which contains references on 850,000 firms in terms of turnover. Three criteria were used to select the sample of firms. Firstly, the firms had to be new ventures. Although Oviatt and McDougall's definition suggests an INV needs to be international "at inception" [5], in general the length of time considered to define an INV varies from three years [21], six years [78], seven years [79], and up to eight years [80] after the firm's creation. Since the aim of this research is to study how international market orientation and capabilities can influence the way INVs use higher resource commitment entry modes in foreign markets, we required our sample firms to have been operating for a maximum of 7 years in order to give them time enough to implement their strategies. Secondly, firms had to be engaged in international activities in a consolidated way; we considered a level of $25 \%$ of annual income coming from foreign markets as a threshold for consolidated international presence. Thirdly, firms could not be subsidiaries or affiliates.

The questionnaire was pretested through personal interviews with 25 CEOs of INVs. Each participant in the pretest answered the questions as s/he read them and verbalized any thoughts that came to mind. The interviewers specifically asked the CEOs to consider ambiguities, inapplicable questions, interesting issues, and so forth. Taking into account the results of these interviews no changes to the items were required.

After applying the above-mentioned selection criteria the total research population was 537 Spanish INVs. For the field research interviewee collaboration was requested together with confirmation of their e-mail address. Once the questionnaire had been sent out, follow-up contact was made by telephone to increase the response rate. The questionnaire was posted on the internet and an e-mail was also sent to each CEO with a link to the questionnaire. A total of 135 firms $(25.14 \%)$ completed the questionnaire. Table 1 summarizes the main characteristics of the sample.

3.2. Measuring Instruments. The two most widely used scales for measuring the degree of market orientation in a firm are the MKTOR scale developed by Narver and Slater [36] and the MARKOR scale proposed by Kohli et al. [81]. They both measure market orientation as a multidimensional concept in which each dimension represents a different characteristic of market orientation. The main problem in opting to use these scales is that they measure market orientation either from a behavioral approach (the MARKOR scale) or from a cultural approach (the MKTOR scale) centered on the customer, without considering distributors and environments as elements of market orientation. This drawback leads us to consider the eclectic scale proposed and validated for the 
Theoretical model A

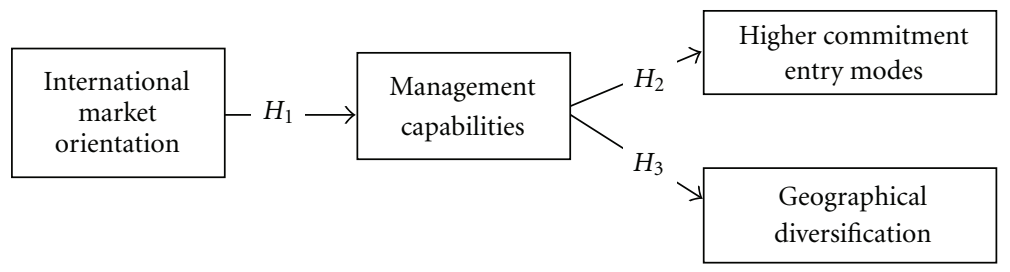

FIGURE 1: Model of effects of international market orientation and management capabilities on INVs' international behavior.

TABLE 1: Characteristics of the sample.

\begin{tabular}{lccccc}
\hline Economic sector & Age & Management team & Turnover & Employees & International income \\
\hline $\begin{array}{l}\text { Main sector where the } \\
\text { company develops its } \\
\text { activity }\end{array}$ & $\begin{array}{c}\text { Number of years from } \\
\text { the creation of the } \\
\text { company }\end{array}$ & $\begin{array}{c}\text { Number of people } \\
\text { within the } \\
\text { management team }\end{array}$ & $\begin{array}{c}\text { Last year approximate } \\
\text { turnover }(\times 1000 €)\end{array}$ & $\begin{array}{c}\text { Number of employees } \\
\text { of the company }\end{array}$ & $\begin{array}{c}\text { Approximate } \\
\text { percentage of income } \\
\text { from foreign markets }\end{array}$ \\
\hline $\begin{array}{l}\text { Industrial }=55.6 \% \\
\text { Services }=17.8 \%\end{array}$ & $1-4=47.4 \%$ & $1-3=75.6 \%$ & Below $800=47.3 \%$ & $3-15=60 \%$ & $25 \%-50 \%=43.2 \%$ \\
Others $=26.6 \%$ & $5=24.4 \%$ & $4-6=20 \%$ & $800-5,000=33.3 \%$ & $16-55=25.4 \%$ & $51 \%-75 \%=35.6 \%$ \\
Mean $(M)$ & $M=4.38$ years old & $M=2.98$ people & $M=20532.35 €$ & $M=25.91$ people & $M=57.284 \%$ \\
\hline
\end{tabular}

Note. The data show the percentage of companies in the total sample that met each criterion.

fieldwork country small and medium firms by Blesa and Bigné [82]. Furthermore, since this paper sets out to measure international market orientation in INVs, following Knight and Cavusgil [38], all the items refer to the international market. Specifically, the scale was made up of five general dimensions (see Table 2): interfunctional coordination, information search, dissemination of information, response design, and response implementation.

In order to measure management capabilities, we adapted the scale developed by [43] to the international context. This scale has also recently been suggested by Weerawardena et al. [83] for application in the specific context of INVs. The scale identifies four dimensions in capabilities based on the typology proposed by Day [39], with the inclusion of a new factor corresponding to relational capability. Thus, capabilities were grouped as follows (see Table 3): outside-in capabilities, inside-out capabilities, spanning capabilities, and relational capabilities.

Regarding the measurement of entry modes, from the literature review we found that most of works that have addressed this variable have been qualitative. In this regard, the criteria used in several recent works allow us to develop a measurement index for entry modes [84-87]. Specifically, respondents were asked to specify the entry mode that they used in their most recent foreign entry [85]. As Table 4 shows the possible response options (export, brand licensing, commercialization, franchising and production agreements, joint-venture, acquisition of a sufficiently high capital share to control a business that was operating in the new market, acquisition of $100 \%$ of the capital of an existing business and creation of a new business or a subsidiary) were arranged hierarchically according to the resources committed to each of them $[84,86,87]$.
In addition, the geographical diversification of INV markets was determined by asking directors to indicate the number of countries in which their firm was present. Firms engaged internationally in a higher number of countries had greater geographical diversification.

3.3. Validity and Reliability of the Scales. Confirmatory factor analysis was performed to purify the international market orientation and management capabilities scales. This methodology allows the researcher to contrast theoretical models in which the representative latent variables of a certain theoretical concept and the indicators designed to measure them are present. Confirmatory factor analysis has become an essential tool in validating measurement scales as a result of these properties [88].

The model was progressively improved by the sequential elimination of the least suitable indicators. Thus, indicators whose standardized coefficients $(\lambda)$ were below .45 [89] and whose Student's $t$-statistic was lower than 2.58 were removed. Following these criteria, we eliminated items Dissem 5 and Imple 4 from international market orientation scale and the indicators Inside 2 and Span 4 from management capabilities.

One diagnostic tool to evaluate internal consistency is the coefficient of reliability that evaluates the consistency of the entire scale, and in which Cronbach's alpha [90] is the most extensively used measurement. Additionally, other complementary reliability tests were carried out: composite reliability of the construct and extracted variance analysis.

A confidence interval test was performed to examine discriminant validity. This test consists of verifying that the value " 1 " does not appear in the estimated confidence intervals for the correlations between each pair of dimensions. 
TABLE 2: Measurement of international market orientation.

Interfunctional coordination

(1) We hold an interdepartmental meeting at least once a quarter to discuss market tendencies and development international market (Coord 1).

(2) The personnel of all our firm's departments hold periodic meetings to jointly plan responses to changes occurring in the international environment (Coord 2).

Information search

(3) We periodically meet with some of our international customers to ascertain their current needs and the products they will need in the future (Search 1).

(4) We systematically gather information on the problems that international distributors may have when marketing our products (Search 2).

(5) We periodically collect information on international distributor satisfaction (Search 3). Information dissemination

(6) The information on end-user satisfaction is systematically distributed to all sections of our firm (Dissem 1).

(7) Sales or marketing personnel devote a great deal of their time to debating potential future needs of the international customers, both amongst themselves and with the rest of the staff (Dissem 2).

(8) High-level managers discuss the strengths and weaknesses of our international competitors with the other managers in the firm (Dissem 3).

(9) When a staff member has important information on our international competitors, he or she quickly alerts other departments in the firm (Dissem 4).

(10) Any information coming from the international market is distributed to all sections in the firm (Dissem 5).

Response design

(11) We periodically revise our products to make sure they match international end-user needs (Design 1).

(12) Our firm ensures its international market strategy is compatible with our international distributors' objectives (Design 2).

Response implementation

(13) We offer full information to our international end-users for better use of our products (Imple 1).

(14) We provide relevant information to our international distributors on our international marketing strategy (Imple 2).

(15) We carry out actions to convince our international distributors of the advantages of working with us (Imple 3).

(16) We participate actively in actions that show the social usefulness of our sector to the general public (Imple 4).

The results of the validity and reliability analyses are shown in Table 5.

3.4. Control Variables. To test for non-response bias, the responses of early and late respondents were compared. The early versus late method of testing for nonresponse bias is based on the premise that early respondents accurately represent the average respondent, while late respondents accurately represent the average nonrespondent. A $t$-test of independent means was performed on the different dimensions of the variables in the proposed model. This test was conducted using the first 45 respondents and last 45 respondents and no significant differences were found between these respondents at the .05 level, indicating an absence of non-response bias [91].

Although we were interested in developing a parsimonious model, other factors that might also influence the relationships had to be considered to ensure results were not unjustifiably affected. International experience was measured by the length of time a firm had been operating internationally [92] and the international experience of its managers. Size is a characteristic that is often used to control for a corporate effect (e.g., $[92,93])$, and this was also incorporated in this study. The rationale is that large firms frequently have a more developed market position than small firms. Size was measured by the previous year's turnover and number of employees, which were used as control variables. ANOVAs were therefore performed to confirm that sample characteristics had no effect on the constructs in the model. No significant differences were found in any of the analyses (see Table 6).

Similarly, a further ANOVA was performed to test for any possible influence of destination country risk on choice of entry mode. Risk has been considered a determinant variable of entry modes. Studies utilizing risk have investigated how perceived levels of risk will often predict levels of control by firms entering foreign markets [94]. Specifically, we consulted the latest version of the International Country Risk Guide (ICRG), produced monthly since 1980 by Political Risk Services, to construct a variable that covered different risk levels according to the countries where the firm was going to sell its products (see Table 7). ICRG is a predictive tool for international investments. It analyses the financial, economic and political environments in developed and emerging countries, providing insight into investment risks and business opportunities, as well as the impact of current and future worldwide events. ICRG incorporates several economic risk factors to determine a country's investment potential, including loan default, delayed payment of suppliers' credits, political leadership, inflation and international 
TABle 3: Measurement of management capabilities.

(1) Mutual trust with our strategic partners (Network 1).

(2) Good at sharing mutual commitment and goals with our strategic partners (Network 2).

(3) Good at pooling expertise with our strategic partners (Network 3).

Outside-in capabilities

(4) Good at creating, maintaining, and enhancing relationships with customers (Outside 1).

(5) Good at ascertaining customers' current needs and what products they will need in the future (Outside 2).

Inside-out capabilities

(6) Strong financial management (Inside 1).

(7) Experience in business management (Inside 2).

(8) Effective human resources management (Inside 3).

(9) Ability to launch successful new products (Span 1).

Spanning capabilities

(10) Quality of customer service (Span 2).

(11) Good marketing management abilities (Span 3).

(12) Good at using information coming from the market (Span 4).

TABLE 4: Measurement of entry modes.

(1) The brand was transferred to another firm that was operating in the new market.

(2) The marketing of our products was subcontracted to a firm in the new market.

(3) Distribution franchising agreements were formalized in the new market.

(4) Our products were exported directly to the new market.

(5) Joint production agreements were formalized with firms that were operating in the new market.

(6) A joint venture was created in the new market.

(7) A share of sufficient capital to control a firm that was operating in the new market was acquired.

(8) $100 \%$ of the capital of an already existing firm in the new market was acquired.

(9) A new firm or a subsidiary was created with capital exclusively from our firm.

TABLE 5: Results of the analyses of reliability of the measurement models.

\begin{tabular}{|c|c|c|c|c|c|c|c|c|}
\hline Scale & & & \multicolumn{3}{|c|}{ Parameters } & $\alpha$ & $\mathrm{CR}$ & EV \\
\hline Intern & market ori & & \multicolumn{3}{|c|}{$0.45-0.90$} & 0.90 & 0.95 & 0.58 \\
\hline Manas & capabilities & & \multicolumn{3}{|c|}{$0.48-0.92$} & 0.71 & 0.89 & 0.46 \\
\hline \multicolumn{9}{|c|}{ Quality of fit measures } \\
\hline$\chi^{2} / d f$ & RMSEA & NFI & CFI & IFI & RFI & RMSR & GFI & AGFI \\
\hline 1.45 & 0.043 & 0.97 & 0.99 & 0.99 & 0.96 & 0.062 & 0.98 & 0.96 \\
\hline
\end{tabular}

TABLE 6: Results of control variables tests.

\begin{tabular}{lcccccccccccc}
\hline \multirow{2}{*}{ Control variable } & ANOVA & & & \multicolumn{3}{c}{ Variable } \\
& & Coord & Search & Dissem & Design & Imple & Network & Outside & Inside & Span & Diver & Entry \\
\hline \multirow{2}{*}{ International age } & $F$ & 0.408 & 0.533 & 1.170 & 0.733 & 0.801 & 1.186 & 0.874 & 1.689 & 1.194 & 1.306 & 0.749 \\
& Sig. & 0.914 & 0.829 & 0.323 & 0.662 & 0.603 & 0.313 & 0.540 & 0.108 & 0.308 & 0.247 & 0.648 \\
Experience & $F$ & 0.518 & 1.680 & 0.695 & 1.431 & 0.730 & 0.761 & 1.828 & 1.089 & 1.427 & 1.451 & 0.620 \\
& Sig. & 0.762 & 0.144 & 0.628 & 0.218 & 0.602 & 0.580 & 0.112 & 0.369 & 0.219 & 0.210 & 0.685 \\
Turnover & $F$ & 0.779 & 0.835 & 0.786 & 0.923 & 1.109 & 0.504 & 0.827 & 0.733 & 0.537 & 0.699 & 1.272 \\
& Sig. & 0.837 & 0.762 & 0.829 & 0.627 & 0.351 & 0.996 & 0.774 & 0.662 & 0.992 & 0.919 & 0.182 \\
Employees & $F$ & 0.674 & 0.592 & 0.728 & 0.539 & 0.664 & 1.121 & 0.591 & 0.863 & 0.609 & 1.044 & 1.127 \\
& Sig. & 0.926 & 0.972 & 0.877 & 0.987 & 0.933 & 0.321 & 0.972 & 0.702 & 0.965 & 0.424 & 0.314 \\
\hline
\end{tabular}




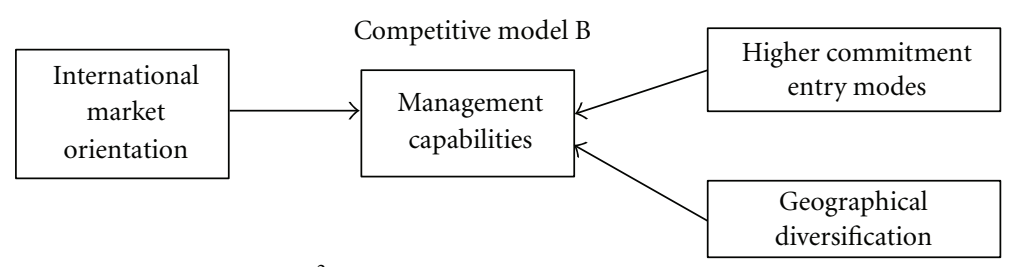

$\chi^{2}=139.87 ; d f=99 ; P=0.00432$

Competitive model C

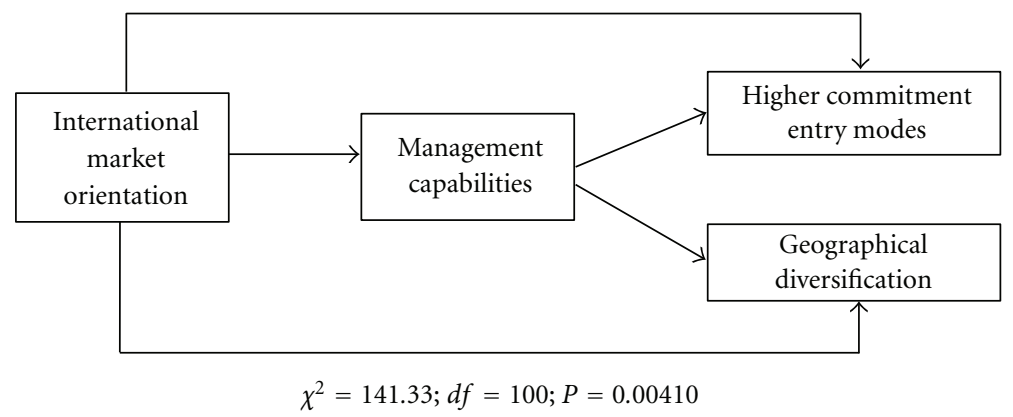

FIgure 2: Competitive models.

TABLE 7: International country risk guide.

\begin{tabular}{lcc}
\hline 1st level of risk & 2nd level of risk & 3rd level of risk \\
\hline $\begin{array}{l}\text { Southeast Asia/China/Japan, Australia/New } \\
\text { Zealand, European Union, North America }\end{array}$ & \multirow{2}{*}{ Russia and Eastern Europe } & $\begin{array}{c}\text { Middle East, Africa, South Asia, South America, Central } \\
\text { America, Arabian Peninsula, Afghanistan/Iran/Turkey }\end{array}$ \\
\hline
\end{tabular}

liquidity ratios. Each country is given a risk rating. This tool has been used in the international business literature for the same purpose as our study $[95,96]$. Our results did not reveal significant differences in the choice of entry mode according to risk level $(F=0.897$; Sig. $=0.579)$.

\section{Results}

As with the scale validations, the hypotheses were tested using structural equations models. These models have proved useful when the research objective is to find the causal contributions of one variable to another in a nonexperimental setting [97]. Furthermore, unlike techniques such as multiple regression, factor analysis, and multivariate analysis of variance, which only allow one relationship to be examined at a time, structural equations model (SEM) analysis can be used to simultaneously explore a series of dependency relationships [98]. Table 8 shows the results of the estimation of the relationship model with SEM using statistical software LISREL 8.8.

Reviewing the main goodness of fit indexes, the literature appears to accept that the RMSEA and the RMSR indexes should not exceed 0.08 ; a value of 0.9 or above is recommended for the NFI; the GFI, CFI, IFI, RFI, and AGFI range from 0 (poor fit) to 1 (perfect fit); finally, values below 5 for the normed chi-square $\left(\chi^{2} / d f\right)$ are indicators that the model fits well [97-100]. According to these recommendations our model presents a good fit with the data.

The results confirm all the hypotheses proposed in the theoretical model. Thus, international market orientation shows a positive and significant relationship with the development of management capabilities in INVs $(\gamma=$ $0.90 ; t=23.14)$, confirming hypothesis $H_{1}$. Moreover, the development of these capabilities has a positive effect on higher commitment entry modes and on the diversification of their presence in foreign markets $(\gamma=0.73 ; t=6.77$ and $\gamma=0.35 ; t=4.54$ resp.), confirming hypotheses $\mathrm{H}_{2}$ and $\mathrm{H}_{3}$.

Evaluation of the model was completed by comparing the proposed model with a competing model acting as alternative explanations for the proposed model. The acceptability of the proposed model can thus be determined according to whether better fit can be achieved with any other similarly formulated model [98, 101-103]. For this purpose, two alternative models are proposed (see Figure 2). The competing model B considers that adopting higher management capabilities could be the result of higher commitment entry modes, which would be the opposite relation to the proposed in this paper. Additionally, it could also be stated that attending to a higher number of foreign markets will provide the firms with a new knowledge that will allow them to achieve greater management capabilities. On the other hand, competing model $\mathrm{C}$ includes the direct effects of international market orientation on higher 
TABLE 8: Results of the estimation of the standardized parameters of the model.

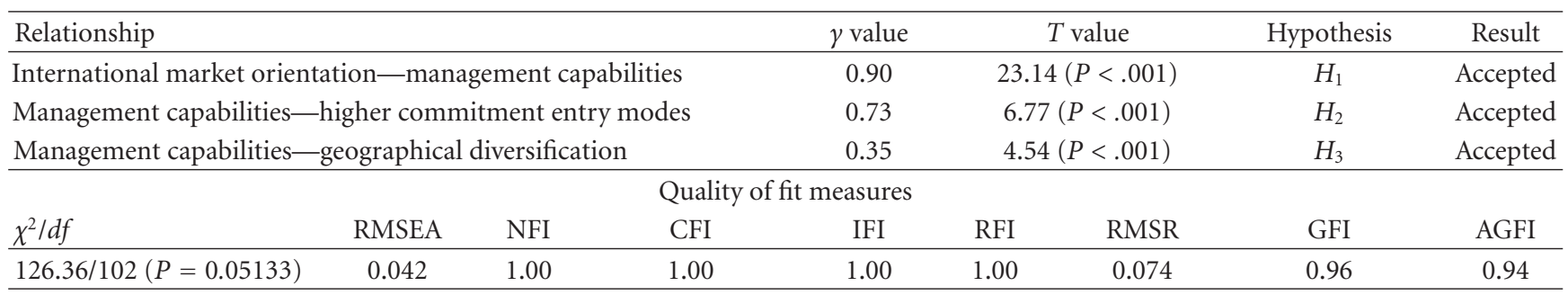

TABle 9: $\Delta \chi^{2}$ differences test.

\begin{tabular}{lcc}
\hline$\chi^{2}$ values & Comparison & Implication \\
\hline$\Delta \chi^{2}=\chi_{\mathrm{B}}^{2}-\chi_{\mathrm{A}}^{2}=13.51$ & $\Delta \chi^{2}>$ Critic value $\chi^{2}$ & The fit of model A is significantly better than the fit of model B. \\
$\Delta d f=\left|d f_{\mathrm{B}}-d f_{\mathrm{A}}\right|=3$ & $13.51>11.34$ & \\
Critic value $\chi^{2}(P<0.01)=11.34$ & $\Delta \chi^{2}>$ Critic value $\chi^{2}$ & The fit of model A is significantly better than the fit of model C. \\
\hline$\Delta \chi^{2}=\chi_{\mathrm{C}}^{2}-\chi_{\mathrm{A}}^{2}=14.97$ & $14.97>9.21$ & \\
$\Delta d f=\left|d f_{\mathrm{C}}-d f_{\mathrm{A}}\right|=2$ & & \\
Critic value $\chi^{2}(P<0.01)=11.34$ & &
\end{tabular}

commitment entry modes and geographical diversification from theoretical model A.

In this sense, direct comparisons can be made through the $\Delta \chi^{2}$ differences test. This test consists of calculating the difference between the values of $\chi^{2}$ regarding both models. If the difference $\Delta \chi^{2}$ is equal to or higher than the value of the table corresponding to the degrees of freedom $\left|d f_{\mathrm{B}}-d f_{\mathrm{A}}\right|$ under a previously selected value of $\alpha$ (in our case $P<0.01$ ) we can conclude that model A is better than model B (see Table 9). The proposed model is accepted in the light of these results for the two competitive models, which strengthens the basis of this work.

\section{Discussion}

The motivation for this study arose from a growing body of literature in international entrepreneurship that increasingly recognizes the importance of INVs to the economic and social progress of ever more globalized economies [104]. But this study extends previous international entrepreneurship research mainly focused on the factors that can promote early international entry $[6,8]$ to include market orientation and management capabilities as a key element in INVs behavior.

Our results confirm that international market orientation associated to early international behavior [38] can be considered an antecedent to the development of management capabilities, which in turn enables INVs to adopt higher commitment entry modes and present a great geographical diversification. These results contrast with one of the main hypotheses raised by the traditional models of internationalization where the firm's experience and its physical presence in international markets have a fundamental role when it comes to explaining how firms acquire capabilities and increase their commitment in international markets $[1,2,17,18]$. In this regard, the traditional view of internationalization may be considered conceptually weak to explain how INVs choose higher resource commitment entry modes.

The results show that firms suffering from the liabilities of newness and foreignness can also choose entry modes that involve higher resource commitment in foreign markets. These results do not coincide with the arguments developed by much of the international entrepreneurship literature, since, due to their entrepreneurial character, it is argued that INVs might prefer to use indirect exporting, licensing, or distribution agreements with international trade agents. INVs' limited resources would lead them to establish relationships with a partner to sell their products in foreign markets that would provide them with the resources necessary to facilitate their growth in international markets [105]. The variable costs borne by INVs through using independent agents will always be lower than the total administrative, marketing and organizational costs associated with the use of higher commitment entry modes [106]. Furthermore, it has been argued that these firms might positively value the use of entry modes that do not involve higher resource commitment in different markets, since these modes could guarantee the operational flexibility they require to operate in these markets $[38,107]$.

However, despite all these arguments, the real situation appears to suggest that INVs can use higher commitment entry modes in their foreign markets $[5,9]$. This study confirms the fact that the lack of tangible resources does not condition the choice of entry mode used by INVs; their choice appears to be motivated by the possession of a set of intangible resources [108], such as the development of management capabilities. In this vein, the present study may complement that of Hashai and Almor [70]. They conclude that, in important markets, wholly owned subsidiaries are the preferred foreign market-servicing mode. Hessels and Terjesen [109] concluded that SMEs are more likely to export using direct mode if they are located in home markets with favorably perceived production costs and access to 
knowledge and technology. Thus, this study has addressed Jones and Young's [32] recommendation to integrate entry mode literature in the study of INV entry modes.

Moreover, comparison of the importance of management capabilities developed by INVs in the geographical diversification of their markets suggests that, in increasingly globalised environments, new companies must concern themselves with developing capabilities related to managing information from foreign markets. Management capabilities enable INVs to adapt their business opportunity to the changing circumstances in their global environment and the specific needs of different local environments. Thus, they must develop the ability to coordinate actions taken in different local markets. This expertise enables INVs to face the challenges of coordination involved in operating on various foreign markets and thus enter new foreign markets and develop a global behavior.

Taken together, our results seem to voice one common message: the management capabilities developed by INVs help to explain the international behavior of these companies [26]. Concretely INVs adopt an international market orientation characterized by a global scope to the different markets that allow these companies to generate valuable information in order to identify new business opportunities. This general information is particularly exploited through the generation of management capabilities, which enable the company to be able to undertake the most appropriate specific actions for each of the markets it serves. In general, these specific actions are characterized by a higher commitment entry modes and a great geographical diversification.

In developing and testing our theoretical model we have also made the following contribution to the literature. While there is an established tradition of researchers that have conceptualized entry mode choices as binary [61, 110-113], our study considers a wide range of entry modes providing a more accurate analysis of the real effects of management capabilities on the choice.

\section{Conclusions, Limitations, and Future Research}

Our conclusions highlight the importance of studying the factors that contribute to explain the INVs' international behavior. Such behavior appears to be motivated by the development of management capabilities. It is evidenced by the successful use of entry modes which involve greater commitment of resources in their foreign markets and presence in a high number of markets.

In developing and testing our model, we make several contributions to the literature. First, this study extends previous international entrepreneurship research mainly focused on the factors that can promote early international entry behavior [114] to include insights on why these INVs can use higher resource commitment entry modes and develop their activity in different geographical markets. Moreover, gaining additional insight into this behavior will ease comparisons with gradualist approaches [27] or other internationalization pathways [7], thus enabling us to better understand the INVs internationalization process from a strategic rather than a structural perspective.

Second, by considering international market orientation and management capabilities as antecedents of new ventures' international behavior, our theoretical model is based on arguments coming from international entrepreneurship literature, marketing literature, and entry mode literature. With this approach, our study also answers the call for multidisciplinary research in international entrepreneurship $[33,34]$. In this sense, considering international market orientation as the first-level influence in the choice of entry mode and geographical diversification is especially important since market orientation is a well-known concept in marketing studies but has received little attention in international entrepreneurship literature. In effect researchers have tended to specialize in international business or entrepreneurship [34].

Third, while there is an established tradition of researchers that have conceptualized entry mode choices as binary [110-113, 115], our study considers a wide range of entry modes providing a more accurate analysis of the real effects of international market orientation and the management capabilities it implies on the choice.

Fourth, given that the capability to manage market information and knowledge can influence firms' international geographical diversification [1], in this paper we also analyse and empirically test whether the development of management capabilities can influence the international geographical diversification of INVs. This analysis is important in that it furthers understanding of the factors that explain how these firms are able to operate in different foreign markets at the same time and to discover how they behave globally, and how this behaviour differs from other international behaviours [25].

Finally, the results of this work encourage entrepreneurs to look beyond the explicit value of experiential market knowledge to realize the potential value of international market orientation to promote key management capabilities and then, higher resource commitment entry modes and high geographical diversification in INVs. In that way the present study questions one of the hypotheses put forward by gradualist models of internationalisation, in which firm experience and physical presence in international markets play a fundamental role in explaining how firms develop their management capabilities [1, 2, 17, 18]. The present paper therefore enhances prior international research by considering a new source for the generation of management capabilities in international markets.

At managerial level, our results imply that entrepreneurs will be capable of generating the necessary relevant information to mitigate the uncertainty and risk associated with the entrepreneurial behaviors and early foreign entry of their firms and, at the same time, to provide factors that support the choice of higher commitment entry modes to expand into foreign markets. To achieve this, he or she must adopt international market intelligence systems that guarantee the generation of information on different markets and environments and its subsequent distribution across all levels of the INV. Furthermore, based on this 
system, the firm will be able to generate the capabilities essential for implementing its general and local policies on foreign markets. The development of these factors enables opportunities to be identified in the most effective way and thus fosters the definition of a coordinated response that allows INVs to enter different geographical markets in a global way and choose specific foreign entry modes to enter to each market involving a greater level of commitment.

Certain limitations of the study should be taken into account when considering the conclusions. First, the use of cross-sectional data to make causal inferences could be seen as a limitation. However, as the main explanatory variables of the proposed model are path-dependent and timeconsuming activities embedded in organizational routines and processes [107], it might be reasonable to assume a causal explanation structure such as we have done in this paper, in which international market orientation has a positive impact that implies the generation of management capabilities. Taking into account the above limitations, future research should study the proposed relationships using longitudinal data and combining positivist and interpretivist methods, such as the one ethnographic or phenomenological methods [34].

Our empirical study was based on common method bias. This procedure raises the question of whether one respondent alone can adequately report for the entire firm. On this issue, as our study is based on new ventures, the entrepreneur can be considered as the appropriate respondent to provide information about new ventures' strategic orientations and the results associated with them [116].

While we believe that our findings are exciting in that they emphasize the value of studying the relationships between international market orientation and management capabilities to explain higher commitment entry modes and geographical diversification in INVs, a multitude of other strategic factors-industry, firm and transaction-related factors $[60,63,117-121]$ — and of other institutional factors [109] can condition that choice. Therefore, we suggest future research analyzes the effect of other factors on INVs entry mode and foreign markets selection choice.

Specialized literature has also noted the importance of firm networks in INVs creation. In their seminal article, Oviatt and McDougall [5] point out that it would not be possible to understand this entrepreneurial phenomenon without taking into account the characteristics of entrepreneurs' networks. Following the works of Coviello and Munro [122], Coviello [123], and Loane and Bell [124], it seems opportune to extend the scope of INV research to include the networks in which they participate exploring the relationship between their networks as fundamental elements to our understanding of the international behavior of these firms.

\section{Acknowledgment}

The authors gratefully acknowledge the support provided by Bancaixa via the research Project "La importancia de la primera cita: Relevancia de la "huella" del primer acuerdo empresarial en el crecimiento internacional de las nuevas empresas" (P11B2009-44).

\section{References}

[1] J. Johanson and J. E. Vahlne, "The internationalization process of the firm: a model of knowledge development and increasing foreign market commitment," Journal of International Business Studies, vol. 8, no. 1, pp. 23-32, 1977.

[2] J. Johanson and J. E. Vahlne, "The mechanism of internationalization,” International Marketing Review, vol. 7, no. 4, pp. 11-24, 1990.

[3] C. O. Mckinsey, Emerging Exporters: Australia's High ValueAdded Manufacturing Exporters, Australian Manufacturing Council, Melbourne, VIC, Australia, 1993.

[4] M. Rennie, Global Competitiveness: Born Global, vol. 4, McKinsey Quarterly, 1993.

[5] B. M. Oviatt and P. P. McDougall, "Toward a theory of international new ventures," Journal of International Business Studies, vol. 36, no. 1, pp. 29-41, 2005.

[6] A. Rialp, J. Rialp, and G. A. Knight, "The phenomenon of early internationalizing firms: what do we know after a decade (1993-2003) of scientific inquiry?" International Business Review, vol. 14, no. 2, pp. 147-166, 2005.

[7] A. Aspelund, T. K. Madsen, and Ø. Moen, "A review of the foundation, international marketing strategies, and performance of international new ventures," European Journal of Marketing, vol. 41, no. 11-12, pp. 1423-1448, 2007.

[8] A. Blesa and M. Ripollés, "The influence of marketing capabilities on economic international performance," International Marketing Review, vol. 25, no. 6, pp. 651-673, 2008.

[9] M. Ripollés, A. Blesa, and D. Monferrer, "Factors enhancing the choice of higher resource commitment entry modes in international new ventures," International Business Review, vol. 21, no. 4, pp. 648-666, 2012.

[10] V. Kumar, A. Stam, and E. A. Joachimsthaler, "An interactive multi-criteria approach to identifying potential foreign markets," Journal of International Marketing, vol. 2, no. 1, pp. 29-52, 1994.

[11] P. Ellis, "Social ties and foreign market entry," Journal of International Business Studies, vol. 31, no. 3, pp. 443-469, 2000.

[12] P. Ellis and A. Pecotich, "Social factors influencing export initiation in small and medium-sized enterprises," Journal of Marketing Research, vol. 38, no. 1, pp. 119-130, 2001.

[13] N. Papadopoulos, H. Chen, and D. R. Thomas, "Toward a tradeoff model for international market selection," International Business Review, vol. 11, no. 2, pp. 165-192, 2002.

[14] X. He and Y. Wei, "Linking market orientation to international market selection and international performance," International Business Review, vol. 20, no. 5, pp. 535-546, 2011.

[15] J. Johanson and F. Wiedersheim-Paul, "The internationalization of the firm - four swedish cases," Journal of Management Studies, vol. 12, no. 3, pp. 305-322, 1975.

[16] O. Andersen and A. Buvik, "Firms' internationalization and alternative approaches to the international customer/market selection," International Business Review, vol. 11, no. 3, pp. 347-363, 2002.

[17] W. J. Bilkey and G. Tesar, "The export behavior of smallersized wisconsin manufacturing firms," Journal of International Business Studies, vol. 8, no. 1, pp. 93-98, 1977. 
[18] T. Cavusgil, "On the internationalization process of firms," European Research, vol. 8, pp. 273-281, 1980.

[19] P. Phillips McDougall, S. Shane, and B. M. Oviatt, "Explaining the formation of international new ventures: the limits of theories from international business research," Journal of Business Venturing, vol. 9, no. 6, pp. 469-487, 1994.

[20] J. Bell, "The internationalization of small computer software firms: a further challenge to stage theories," European Journal of Marketing, vol. 29, no. 8, pp. 60-65, 1995.

[21] T. K. Madsen and P. Servais, "The internationalization of born globals: an evolutionary process?" International Business Review, vol. 6, no. 6, pp. 561-583, 1997.

[22] B. M. Oviatt and P. P. McDougall, "Defining international entrepreneurship and modeling the speed of internationalization," Entrepreneurship, vol. 29, no. 5, pp. 537-553, 2005.

[23] G. S. Yip, J. G. Biscarri, and J. A. Monti, "The role of the internationalization process in the performance of newly internationalizing firms," Journal of International Marketing, vol. 8, no. 3, pp. 10-35, 2000.

[24] L. Li, D. Li, and T. Dalgic, "Internationalization process of small and medium-sized entreprises: toward a hybrid model of experiential learning and planning," Management International Review, vol. 44, no. 1, pp. 93-117, 2004.

[25] M. Gabrielsson, V. H. M. Kirpalani, P. Dimitratos, C. A. Solberg, and A. Zucchella, "Born globals: propositions to help advance the theory," International Business Review, vol. 17, no. 4, pp. 385-401, 2008.

[26] A. Blesa, M. Ripollés, and D. Monferrer, "Marketing capabilities: do they matter in INVs?" World Review of Entrepreneurship, Management and Sustainable Development, vol. 6, no. 1-2, pp. 71-99, 2010.

[27] M. V. Jones and N. E. Coviello, "Internationalisation: conceptualising an entrepreneurial process of behaviour in time," Journal of International Business Studies, vol. 36, no. 3, pp. 284-303, 2005.

[28] A. Blomstermo, K. Eriksson, A. Lindstrand, and D. D. Sharma, "The perceived usefulness of network experiential knowledge in the internationalizing firm," Journal of International Management, vol. 10, no. 3, pp. 355-373, 2004.

[29] A. Blesa, D. Monferrer, Y. Nauwelaerts, and M. Ripollés, “The effect of early international commitment on international positional advantages in Spanish and Belgian international new ventures," Journal of International Entrepreneurship, vol. 6, no. 4, pp. 168-187, 2008.

[30] J. M. Armario, D. M. Ruiz, and E. M. Armario, "Market orientation and internationalization in small and mediumsized enterprises," Journal of Small Business Management, vol. 46, no. 4, pp. 485-511, 2008.

[31] J. Degadt, "Internationalization of SMEs in Belgium," in Handbook of Research on European Bunsiness and Entrepreneurship, L. P. Dana, I. M. Welpe, M. Han, and V. Ratten, Eds., pp. 77-93, Edward Elgar, Cheltenham, UK, 2008.

[32] M. V. Jones and S. Young, "Does entry mode matter? Reviewing current themes and perspectives," in Internationalization Entrepreneurship and the Smaller Firm. Evidence From Around the World, M. V. Jones, P. Dimitratos, M. Fletcher, and S. Young, Eds., pp. 6-19, Edward Elgar, Cheltenham, UK, 2009.

[33] P. P. McDougall and B. M. Oviatt, "International entrepreneurship: the intersection of two research paths," Academy of Management Journal, vol. 43, no. 5, pp. 902-906, 2000.
[34] N. E. Coviello and M. V. Jones, "Methodological issues in international entrepreneurship research," Journal of Business Venturing, vol. 19, no. 4, pp. 485-508, 2004.

[35] A. K. Kohli and B. J. Jaworski, "Market orientation: the construct, research propositions and managerial implications," Journal of Marketing, vol. 54, no. 2, pp. 1-18, 1990.

[36] J. C. Narver and S. F. Slater, "The effect of market orientation on business profitability," Journal of Marketing, vol. 54, no. 4, pp. 20-35, 1990.

[37] J. W. Cadogan, N. J. Paul, R. T. Salminen, K. Puumalainen, and S. Sundqvist, "Key antecedents to "export" marketoriented behaviors: a cross-national empirical examination," International Journal of Research in Marketing, vol. 18, no. 3, pp. 261-282, 2001.

[38] G. A. Knight and S. T. Cavusgil, "Innovation, organizational capabilities, and the born-global firm," Journal of International Business Studies, vol. 35, no. 2, pp. 124-141, 2004.

[39] G. S. Day, "The capabilities of Market-Driven Organizations," Journal of Marketing, vol. 58, no. 4, pp. 37-52, 1994.

[40] J. Weerawardena, "The role of marketing capability in innovation-based competitive strategy," Journal of Strategic Marketing, vol. 11, pp. 15-35, 2003.

[41] G. E. Greenley, G. J. Hooley, A. J. Broderick, and J. M. RUDD, "Strategic planning differences among different multiple stakeholder orientation profiles," Journal of Strategic Marketing, vol. 12, no. 3, pp. 163-182, 2004.

[42] D. W. Vorhies and N. A. Morgan, "Benchmarking marketing capabilities for sustainable competitive advantage," Journal of Marketing, vol. 69, no. 1, pp. 80-94, 2005.

[43] G. Hooley, G. Greenley, and J. Fahy, "A scale for measuring marketing capabilities," in Proceedings of the 31st The European Marketing Academy Conference (EMAC'02), Braga, Portugal, May 2002.

[44] J. E. Butler, B. Brown, and W. Chamornmarn, "Informational networks, entrepreneurial action and performance," Asia Pacific Journal of Management, vol. 20, no. 2, pp. 151-174, 2003.

[45] J. H. Dunning, "Alternative channels and modes of international resource transmission," in Controlling International Technology Transfer: Issues, Perspectives and Implications, T. Sagafi-Nejad, H. Perlmutter, and R. Moxon, Eds., Permagon, New York, NY, USA, 1981.

[46] E. Autio, H. J. Sapienza, and J. G. Almeida, "Effects of age at entry, knowledge intensity, and imitability on international growth," Academy of Management Journal, vol. 43, no. 5, pp. 909-924, 2000.

[47] E. Autio, H. J. Sapienza, and P. Arenius, "International social capital, technology sharing, and foreign market learning in internationalizing entrepreneurial firms," Advances in Entrepreneurship, Firm Emergence and Growth, vol. 8, pp. 942, 2005.

[48] I. Nonaka, R. Toyama, and N. Konno, "SECI, Ba and leadership: a unified model of dynamic knowledge creation," Long Range Planning, vol. 33, no. 1, pp. 5-34, 2000.

[49] I. Becerra-Fernandez and R. Sabherwal, "Organizational knowledge management: a contingency perspective," Journal of Management Information Systems, vol. 18, no. 1, pp. 23-55, 2001.

[50] Y. Wang, P. Ahmed, and S. Farquhar, "Founders versus descendants: the profitability, growth and efficiency characteristics comparison in the UK small and medium sized family businesses," Journal of Entrepreneurship, vol. 16, no. 2, pp. 173-195, 2007. 
[51] I. Nonaka and H. Takeuchi, The Knowledge-Creating Company, Oxford University Press, Oxford, UK, 1995.

[52] T. Davenport and L. Prusak, Working Knowledge, Harvard Business School Press, Boston, Mass, USA, 1998.

[53] Y. Luo, "Dynamic capabilities in international expansion," Journal of World Business, vol. 35, no. 4, pp. 355-378, 2000.

[54] D. J. Teece, G. Pisano, and A. Shuen, "Dynamic capabilities and strategic management," Strategic Management Journal, vol. 18, no. 7, pp. 509-533, 1997.

[55] M. Tsai and C. Shih, "The impact of marketing knowledge among managers on marketing capabilities and business performance," International Journal of Management, vol. 21, no. 4, pp. 524-530, 2004.

[56] S. S. Liu, X. Luo, and Y. Z. Shi, "Integrating customer orientation, corporate entrepreneurship, and learning orientation in organizations-in-transition: an empirical study," International Journal of Research in Marketing, vol. 19, no. 4, pp. 367-382, 2002.

[57] S. N. Bhuian, B. Menguc, and S. J. Bell, "Just entrepreneurial enough: the moderating effect of entrepreneurship on the relationship between market orientation and performance," Journal of Business Research, vol. 58, no. 1, pp. 9-17, 2005.

[58] D. W. Vorhies and M. Harker, "The capabilities and performance advantages of market-driven firms: an empirical investigation," Australia Journal of Management, vol. 25, no. 2, pp. 145-173, 2000.

[59] A. Mazaira, A. Dopico, and E. GonzÁlez, "Incidencia en el grado de orientación al mercado de las organizaciones empresariales en el desarrollo de las capacidades estratégicas de marketing," Revista Europea de Dirección y Economía de la Empresa, vol. 14, no. 3, pp. 181-208, 2005.

[60] E. Anderson and H. Gatignon, "Modes of foreign entry: a transaction cost analysis and propositions," Journal of International Business Studies, vol. 17, no. 3, pp. 1-26, 1986.

[61] A. McAuley, "Entrepreneurial instant exporters in the Scottish arts and crafts sector," Journal of International Marketing, vol. 7, no. 4, pp. 67-82, 1999.

[62] S. Zaheer, "Overcoming the liability of foreignness," Academy of Management Journal, vol. 38, pp. 341-363, 1995.

[63] W. C. Kim and P. Hwang, "Global strategy and multinationals' entry mode choice," Journal of International Business Studies, vol. 23, no. 1, pp. 29-54, 1992.

[64] A. Madhok, "The nature of multinational firm boundaries: transaction costs, firm capabilities and foreign market entry mode," International Business Review, vol. 7, no. 3, pp. 259290, 1998.

[65] Y. Luo, "Equity sharing in international joint ventures: an empirical analysis of strategic and environmental determinants," Journal of International Management, vol. 7, no. 1, pp. $31-58,2001$.

[66] I. Nonaka, "A dynamic theory of organizational knowledge creation," Organization Science, vol. 5, no. 1, pp. 14-37, 1994.

[67] R. R. Nelson and S. G. Winter, An Evolutionary Theory of Economic Change, Belknap Press, Cambridge, UK, 1982.

[68] M. A. Peteraf and M. E. Bergen, "Scanning dynamic competitive landscapes: a market-based and resource-based framework," Strategic Management Journal, vol. 24, no. 10, pp. 1027-1041, 2003.

[69] M. Zain and S. I. Ng, "The impacts of network relationships on SMEs' internationalization process," Thunderbird International Business Review, vol. 48, no. 2, pp. 183-205, 2006.

[70] N. Hashai and T. Almor, "Gradually internationalizing 'born global' firms: an oxymoron?" International Business Review, vol. 13, no. 4, pp. 465-483, 2004.
[71] R. G. Cooper and E. J. Kleinschmidt, "The impact of export strategy on export sales performance," Journal of International Business Studies, vol. 16, no. 1, pp. 37-56, 1985.

[72] I. Ayal and J. Raban, "Developing hi-tech industrial products for world markets," IEEE Transactions on Engineering Management, vol. 37, no. 3, pp. 177-184, 1990.

[73] T. K. Madsen, E. Rasmussen, and P. Servais, "Differences and similarities between born globals and other types of exporters," Advances in International Marketing, vol. 10, pp. 247-265, 2000.

[74] C. A. Bartlett and S. Ghoshal, "The myth of the generic manager: new personal competencies for new management roles," California Management Review, no. 1, pp. 92-116, 1997.

[75] K. Eriksson, J. Johanson, A. Majkgård, and D. D. Sharma, "Experiential knowledge and cost in the enternationalization process," Journal of International Business Studies, vol. 28, no. 2, pp. 337-360, 1997.

[76] C. Brush, Factors motivating small firms to internationalize: the effects of firm age [Ph.D. thesis], Boston University, Boston, MA, USA, 1992.

[77] P. L. Yeoh, "International learning: antecedents and performance implications among newly internationalizing companies in an exporting context," International Marketing Review, vol. 21, no. 4-5, pp. 511-535, 2004.

[78] S. A. Zahra, R. D. Ireland, and M. A. Hitt, "International expansion by new venture firms: international diversity, mode of market entry, technological learning, and performance," Academy of Management Journal, vol. 43, no. 5, pp. 925-950, 2000.

[79] V. K. Jolly, M. Alahuhta, and J. P. Jeanet, "Challenging the incumbents: how high technology start-ups compete globally," Journal of Strategic Change, vol. 1, pp. 71-82, 1992.

[80] P. P. McDougall and B. M. Oviatt, "New venture internationalization, strategic change, and performance: a follow-up study," Journal of Business Venturing, vol. 11, no. 1, pp. 23-40, 1996.

[81] A. K. Kohli, B. J. Jaworski, and A. Kumar, "MARKOR: a measure of market orientation," Journal of Marketing Research, vol. 30, no. 4, pp. 467-477, 1993.

[82] A. Blesa and E. Bigné, "The effect of market orientation on dependence and satisfaction in dyadic relationships," Marketing Intelligence and Planning, vol. 23, no. 3, pp. 249$265,2005$.

[83] J. Weerawardena, G. S. Mort, P. W. Liesch, and G. Knight, "Conceptualizing accelerated internationalization in the born global firm: a dynamic capabilities perspective," Journal of World Business, vol. 42, no. 3, pp. 294-306, 2007.

[84] Y. Pan and D. K. Tse, "The hierarchical model of market entry modes," Journal of International Business Studies, vol. 31, no. 4, pp. 535-554, 2000.

[85] G. Nakos and K. D. Brouthers, "Entry mode choice of SMEs in Central and Eastern Europe," Entrepreneurship Theory and Practice, vol. 27, no. 1, pp. 47-64, 2002.

[86] C. Kalantaridis, "Internationalization, strategic behavior, and the small firm: a comparative investigation," Journal of Small Business Management, vol. 42, no. 3, pp. 245-262, 2004.

[87] Y. Wei, B. Liu, and X. Liu, "Entry modes of foreign direct investment in China: a multinomial logit approach," Journal of Business Research, vol. 58, no. 11, pp. 1495-1505, 2005.

[88] J. B. E. M. Steenkamp and H. C. M. van Trijp, "The use of lisrel in validating marketing constructs," International Journal of Research in Marketing, vol. 8, no. 4, pp. 283-299, 1991. 
[89] L. Hildebrandt, "Consumer retail satisfaction in rural areas: a reanalysis of survey data," Journal of Economic Psychology, vol. 8, no. 1, pp. 19-42, 1987.

[90] J. Nunnally, Psychometric Theory, McGraw-Hill, New York, NY, USA, 1979.

[91] J. S. Armstrong and T. S. Overton, "Estimating non-response bias in mail surveys," Journal of Marketing Research, vol. 16, pp. 396-402, 1977.

[92] C. R. Taylor, S. Zou, and G. E. Osland, "Foreign market entry strategies of Japanese MNCs," International Marketing Review, vol. 17, no. 2, pp. 146-163, 2000.

[93] K. Buysse and A. Verbeke, "Proactive environmental strategies: a stakeholder management perspective," Strategic Management Journal, vol. 24, no. 5, pp. 453-470, 2003.

[94] A. Canabal and G. O. White III, "Entry mode research: past and future," International Business Review, vol. 17, no. 3, pp. 267-284, 2008.

[95] P. J. Buckley, L. J. Clegg, A. R. Cross, X. Liu, H. Voss, and P. Zheng, "The determinants of Chinese outward foreign direct investment," Journal of International Business Studies, vol. 38, no. 4, pp. 499-518, 2007.

[96] J. L. Duanmu and Y. Guney, "A panel data analysis of locational determinants of chinese and indian outward foreign direct investment," Journal of Asia Business Studies, vol. 3, no. 2, pp. 1-15, 2009.

[97] K. G. Jöreskog and D. Sörbom, LISREL 8. Structural Equation Modeling With the SIMPLIS Command Language, Scientific Software, Hillsdale, NJ, USA, 1993.

[98] J. F. Hair, W. C. Black, B. J. Babin, R. E. Anderson, and R. L. Tatham, Multivariate Data Analysis, Pearson Education, Upper Saddle River, NJ, USA, 6th edition, 2006.

[99] P. M. Bentler and C. P. Chou, "Practical issues in structural modeling," Sociological Methods \& Research, vol. 16, pp. 78$117,1987$.

[100] K. A. Bollen, "Overall fit in covariance structure models: two types of sample size effects," Psychological Bulletin, vol. 107, no. 2, pp. 256-259, 1990.

[101] J. C. Anderson and D. W. Gerbing, "Structural equation modeling in practice: a review and recommended two-step approach," Psychological Bulletin, vol. 103, no. 3, pp. 411-423, 1988.

[102] G. Yukl, Leadership in Organizations, Pearson Prentice Hall, Upper Saddle River, NJ, USA, 6th edition, 2006.

[103] T. L. Friedrich, C. L. Byrne, and M. D. Mumford, "Methodological and theoretical considerations in survey research," Leadership Quarterly, vol. 20, no. 2, pp. 57-60, 2009.

[104] J. Hessels and A. Van Stel, "Export orientation among new ventures and economic growth. Erasmus Research Institute of Management (ERIM)," Report Series 2007-008, Erasmus University Rotterdam, Rotterdam, The Netherlands, 2007.

[105] A. L. Zacharakis, "Entrepreneurial entry into foreign markets: a transaction cost perspective," Entrepreneurship Theory and Practice, vol. 21, no. 3, pp. 23-39, 1997.

[106] C. Zheng and S. Khavul, "Capability development, learning and growth in international entrepreneurial firms: evidence from China," Advances in Entrepreneurship, Firm Emergence and Growth, vol. 8, pp. 273-296, 2005.

[107] A. Jantunen, K. Puumalainen, S. Saarenketo, and K. Kyläheiko, "Entrepreneurial orientation, dynamic capabilities and international performance," Journal of International Entrepreneurship, vol. 3, no. 3, pp. 223-243, 2005.
[108] K. C. Gleason and J. Wiggenhorn, "Born globals, the choice of globalization strategy, and the market's perception of performance," Journal of World Business, vol. 42, no. 3, pp. 322-335, 2007.

[109] J. Hessels and S. Terjesen, "Resource dependency and institutional theory perspectives on direct and indirect export choices," Small Business Economics, vol. 34, no. 2, pp. 203220, 2010.

[110] W. H. Davidson and D. G. Mcfetridge, "Key characteristics in the choice of international technology transfer mode," Journal of International Business Studies, vol. 16, pp. 5-21, 1985.

[111] B. Kogut and H. Singh, "The effect of national culture on the choice of entry mode," Journal of International Business Studies, vol. 19, no. 3, pp. 411-432, 1988.

[112] H. G. Barkema and F. Vermeulen, "International expansion through start-up or acquisition: a learning perspective," Academy of Management Journal, vol. 41, no. 1, pp. 7-26, 1998.

[113] O. Burgel and G. C. Murray, "The international market entry choices of start-up companies in high-technology industries," Journal of International Marketing, vol. 8, no. 2, pp. 33-62, 2000.

[114] S. A. Zahra and G. George, "Absorptive capacity: a review, reconceptualization, and extension," Academy of Management Review, vol. 27, no. 2, pp. 185-203, 2002.

[115] M. K. Erramilli and C. P. Rao, "Service firms'internacional entry-mode choice: a modified transaction cost analysis approach," Journal of Marketing, vol. 57, pp. 19-38, 1993.

[116] P. Davidsson, "Scott shane, a general theory of entrepreneurship: the individual opportunity nexus," International Small Business Journal, vol. 22, no. 2, pp. 206-209, 2004.

[117] G. S. Yip, Barriers To Entry: A Corporate Perspective, Lexicon Books, Lexicon, Mass, USA, 1982.

[118] G. S. Yip, "Diversification entry: internal development versus acquisition," Strategic Management Journal, vol. 3, pp. 331$345,1982$.

[119] I. Ekeledo and K. Sivakumar, "International market entry mode strategies of manufacturing firms and service firms: a resource-based perspective," International Marketing Review, vol. 21, no. 1, pp. 68-10, 2004.

[120] K. D. Brouthers and G. Nakos, "SME entry mode choice and performance: a transaction cost perspective," Entrepreneurship, vol. 28, no. 3, pp. 229-247, 2004.

[121] A. Pehrsson, "The strategic states model: strategies for business growth," Business Strategy Series, vol. 8, no. 1, pp. 58-63, 2007.

[122] N. E. Coviello and H. J. Munro, "Growing the entrepreneurial firm networking for international market development," European Journal of Marketing, vol. 29, no. 7, pp. 49-61, 1995.

[123] N. E. Coviello, "The network dynamics of international new ventures," Journal of International Business Studies, vol. 37, no. 5, pp. 713-731, 2006.

[124] S. Loane and J. Bell, "Rapid internationalisation among entrepreneurial firms in Australia, Canada, Ireland and New Zealand: an extension to the network approach," International Marketing Review, vol. 23, no. 5, pp. 467-485, 2006. 


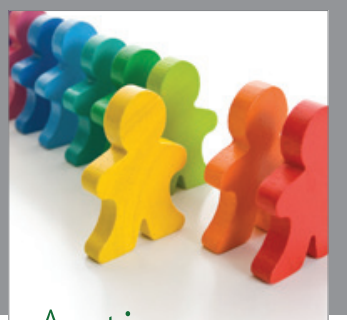

Autism

Research and Treatment
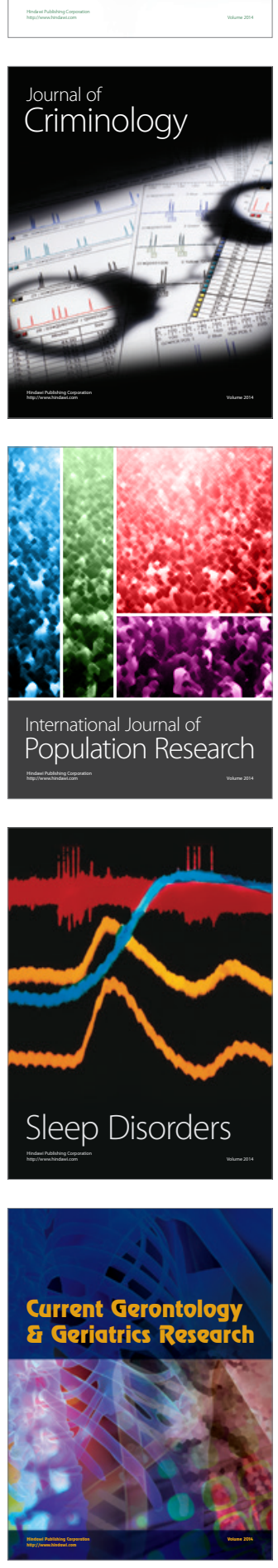
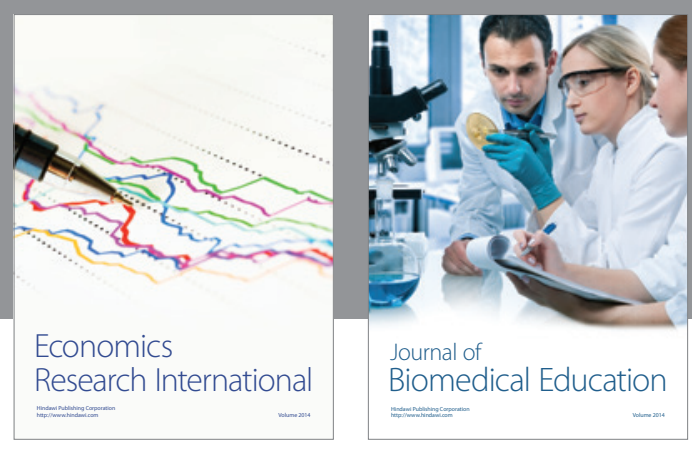

Journal of

Biomedical Education

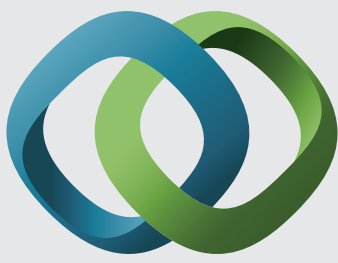

\section{Hindawi}

Submit your manuscripts at

http://www.hindawi.com
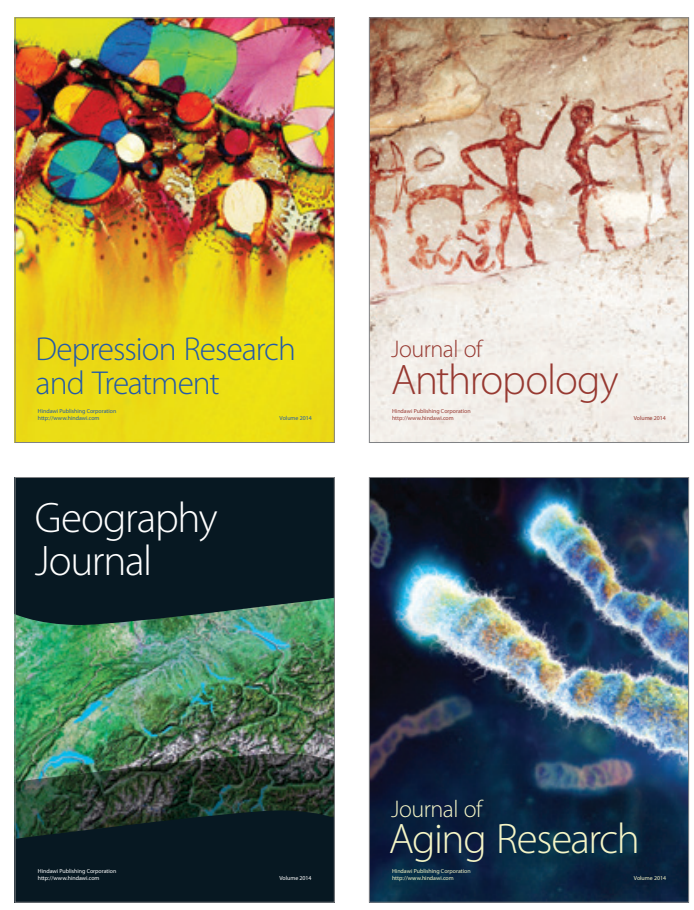

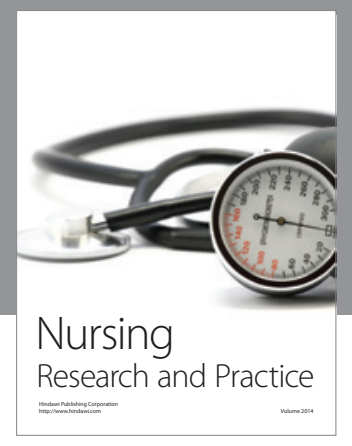

Nursing

Research and Practice

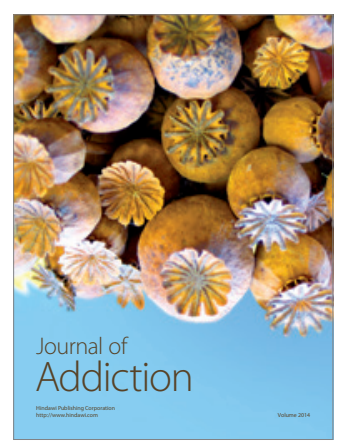

Child Development

Research

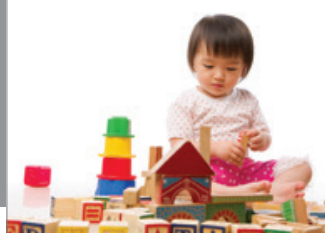

迥
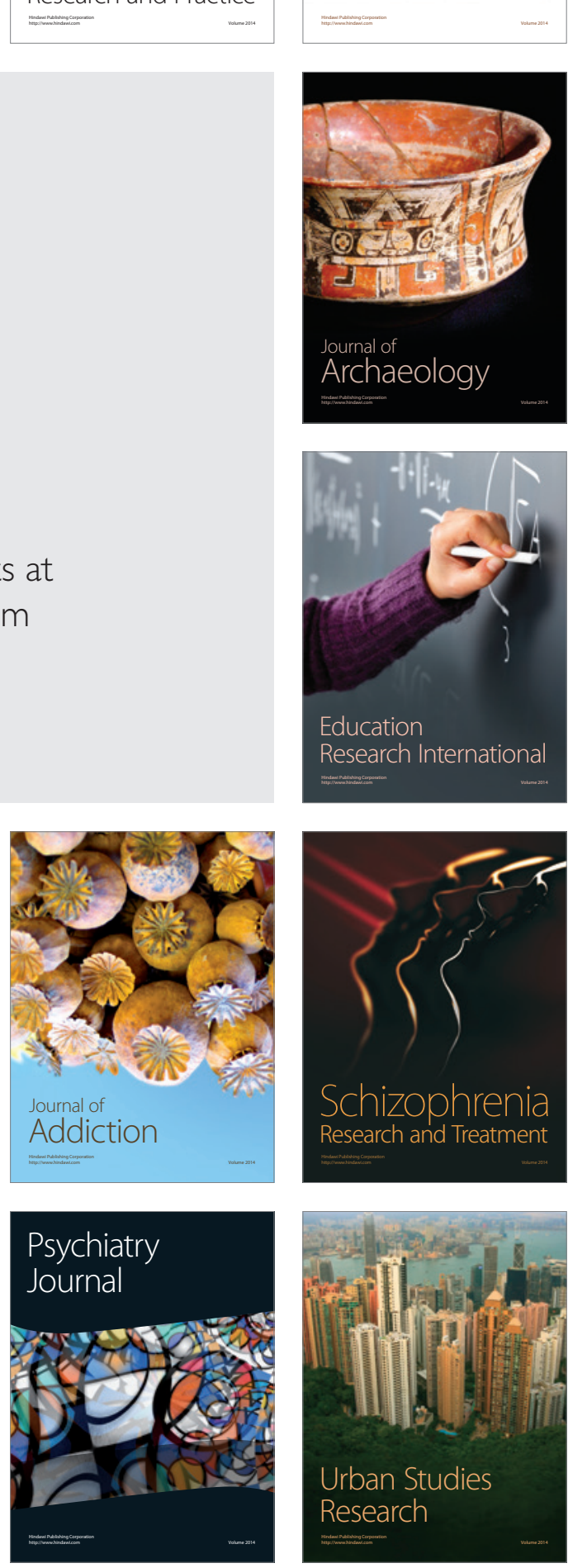